\title{
The Determinants of Capital Structure and Dividend Policy: Empirical Evidence from the Kingdom of Saudi Arabia Market
}

\author{
Sherif El-Halaby \\ Accounting Department, Business School, \\ 45 Arab Open University, Kuwait and MSA University, Egypt \\ Email: sismail@aou.edu.kw \\ Email: selhalaby@msa.eun.eg \\ *Corresponding author \\ Mohammed Alzunaydi \\ Business School, Plymouth University, UK \\ And \\ Mahmoud El-Ghazaly \\ Accounting Department, Business School \\ MSA University, Egypt
}

Received Feb, 2017; Accepted April, 2018

\begin{abstract}
This paper investigates the main factors determining the dividend payout policy and the capital structure decision in the Kingdom of Saudi Arabia (KSA). The sample includes 91 non-financial firms listed on the KSA stock market (Tadawal Stock Exchange) for the period between 2012 and 2016. Two models are used mainly the Ordinary Least Square (OLS) for the capital structure decision and Logistic Regression (LR) for the dividend policy decision. OLS results show that the capital structure is positively affected by the firm size, but negatively affected by liquidity, tangible assets, and lagged dividends. However, other variables such as profitability, the current dividend payout ratio, growth opportunities, and life cycle are found to have no impact on the capital structure decision. Furthermore, LR results show that the significant determinants of dividend payout decision are profitability, growth opportunity, and lagged dividends. These results show that the capital structure and the dividend payout decisions are determined differently.
\end{abstract}

Keywords: Capital Structure; Dividends; Determinants; KSA

Type: Research paper

This work is licensed under a Creative Commons Attribution 4.0 International License.

\section{DOI: 10.51325/ijbeg.v1i2.16}

\section{Introduction}

Dividend policy and capital structure are contentious topics in the business finance community. Academics are still concerned with examining the diverse methods and techniques used in various markets (Al-Najjar, 2011). This study examines capital structure and dividend policy independently; however, it investigates the individual determinants as well the combined determinants for both. The connection between dividend policy and capital structure is an under-investigated subject with regard to developed and emerging markets. We therefore seek to explore this link in the emerging market of KSA as well as to explore the main determinants behind the association. There have been many previous studies on corporate financial policy. Dividend policy and capital structure in particular have been studied in depth, dating back to the seminal arguments of Modigliani and Miller (1958). Two features of these previous studies are 
remarkable. Firstly, theories about capital structure differ from theories about dividend policy. Previous studies have treated capital structure and dividend policy as two separate choices, although there is evidence to support the idea that there are joint features affecting both. Secondly, the practical application of these theories has had mixed results, which has opened the door to a number of unresolved inquiries.

This study adds to previous research by testing the key factors that affect dividend policy and capital structure in the listed KSA firms. KSA has a distinctive environment that remains largely unknown (Al-Ajmi et al., 2009). This study considers numerous explanations. First, corporations in KSA must pay Zakat (Islamic Interest). This is the Third Column of Islam and is an obligation for individual Muslims as well as corporations. Furthermore, KSA companies work in an atmosphere categorised by the absence of a subordinate liability market, relying principally on credit and lending from commercial banks. KSA's legal system is based on Sharia (Islamic Law). In the KSA economy, the government plays a strong role characterised by heavy expenditure and possession of the oil manufacturing industry, which represents approximately $32 \%$ of KSA's GDP. Firms deal with commercial banks as the key option for outside funding. They also rely to a lesser degree on Sukuk (Islamic bonds) for funding. Strong associations between companies and banks help to moderate agency costs and information asymmetries between borrowers and banks. Additionally, according to Beck et al (2002), corporations in emerging markets such as KSA tend to rely on internal resources, as they face enormous complications when attempting to access external funding markets.

KSA's banking structure is categorised as a dual banking system, as it includes Islamic banks in addition to conventional banks. Islamic banks comply with Sharia and therefore do not offer loans with interest. They thus do not provide financial services comparable with those provided by conventional banks. Based on Sharia, Islamic banks provide their customers with sharing services dependant on equity-based products such as Murabaha and Musharakah (Khan and Bhatti, 2008). Sharia prohibits receiving or paying Riba on credit. Muslims are prohibited from investing their money in corporations that have a liability percentage above 33\% (SAMA, 2015). Consequently, KSA companies tend to hold firmly to the $33 \%$ cap to avoid losing shareholders. If a corporation surpasses this limit, it risks being omitted from Sharia-compliant groups. This may have an impact on the company's capital structure choices, as it would then be compulsory to use internal funding and to continue to replace borrowing capability.

The capital marketplace in KSA is emerging, and asymmetric information between stockholders and firms may have a significant impact on company capital structure. These influences have encouraged investigating their effects on capital structure policy. Furthermore, KSA firms tend to hold on to their dividends or to pay out small amounts, thus supporting the interpretation that KSA firms do not employ dividends as a method of signalling or decreasing asymmetric information. These difficulties are reduced when banks are the key suppliers of finance. These features of the KSA market have encouraged investigating dividend policy in KSA. The connection between capital structure and dividend policy is still an under-investigated subject with regard to emerging and developed marketplaces. A few rare studies have attempted to empirically define the factors affecting capital structure and dividend choices in KSA; however, these studies have suffered from methodological complications. There is an absence of harmony in practical examination among researchers who have studied KSA capital structure and dividend choices, namely Al-Ajmi et al (2009); Al-Sakran (2001). The association between company variables and dividend policy has been widely studied in UK as well as US companies (Eckbo and Verna, 1994; Jensen et al., 1992). However, the possible association between dividend policy and corporation characteristics in other countries is 
mainly unexplored. The incentive motivation to conduct this study comes from existing hypothetical arguments in business finance relating to ideal capital structure and its factors and to features influencing dividend pay-out policies. This study provides understanding to managers about the inter-correlation between capital structure and dividend policy, thus allowing them to plan more efficiently. This investigation enables researchers and experts to better understand the diverse approaches to dividend policy and capital structure. It is important to interpret the compound association between capital structure and dividend policy to allow corporations and stockholders to comprehend many choices that they must make in an ever-changing financial environment.

This research seeks to add to the body of corporate finance literature by examining choices relating to dividend policy and capital structure. The contribution of this paper is not just investigates the determinants of dividend policy and capital structure but also the interaction between these variables. This study fills the gap between hypothetical and practical research by examining financial limitations in a sample of KSA firms. As far as we know, this is the first study to evaluate this subject in KSA. Secondly, this research seeks to determine whether theories of capital structure are appropriate for the KSA market. The current development of new models of capital structure theory, particularly pecking order theory (Frank and Goyal, 2003); have been confirmed by using data from developed markets, with insufficient application in emerging markets. This study aims to build on current theoretical research by focusing on developing markets in contrast with developed markets. In previous studies, most hypothetical and practical research dealing with funding decisions has been US-based. However, several developing markets are undergoing a process of modification, development and liberalisation that provides a motivating and challenging ground for Western-based business philosophy.

This paper differs from the previous studies in several ways. Studies by Al-Ajmi et al (2009); Huizinga et al (2008) focused only on factors affecting capital structure, while Denis and Osobov (2008) focused only on dividend policy. This study, on the other hand, focuses on both of variables (capital structure and dividends policy). The data from this research is updated from previous studies, such as that done by Al-Najjar (2011), who focused on 2003. This study tests multiple theories, including pecking order theory, agency theory and lifecycle theory, where as De Angelo et al (2006) focused only on lifecycle theory. This study's sample (90 firms) is larger than the samples in previous studies (Zameer et al., 2013) used data from 27 firms). The paper is organised as follows: section 2 discusses the theoretical framework for capital structure as well as dividends policy, while section 3 demonstrates the literature reviews. Section $\mathbf{4}$ outlines the development of hypotheses which discuses main determinants of capital structure and dividends policy. In sections 5, data and methodology are discussed. In section $\mathbf{6}$, statistical results are presented and discussed, while finally section 7 covers the conclusions of the study.

\section{Theoretical Framework}

The study of the factors or determinants effecting dividend policy and capital structure is important in order that certain related control variables can be considered when analyzing the influence of definite characteristics of the issues studied. These variables should be selected according to existing theories, and the practical indications associated with dividend strategy and capital structure. Established theories on this subject are usually based upon the recognized conclusions established by Modigliani and Miller (1958). The leading theories on dividend policy are: Lifecycle theory; Signalling theory and Agency theory (e.g. Lang and Litzenberger (1989); Miller and Rock (1985); John and 
Williams (1985); Easterbrook (1984)). The most important capital structure theories are Agency theory; Pecking Order theory and Trade-Off Theory.

\section{Capital structure theories}

Trade-Off Theory: This theory claims that firm's leverage strategy is a balance between the costs and paybacks of liability funding; where the capital structure costs comprise agency costs and insolvency costs, as well as the benefits resulting from the minimizing of free-cash-flow difficulties and the debt tax shield (Stulz, 1990). The theory forecasts that a growth in share price should, as it lowers the corporation's leverage percentage, lead to liability issuance through corporation which will bring its leverage degree back to an optimum level. Trade-off theory suggests that there is equilibrium between the costs and returns of leverage in the company. This model is posited by Kraus and Litzenberger (1973) who argue that "...the value of the levered corporation is equivalent to the value of the unlevered corporation plus the contemporary value of the tax advantage after subtracting the costs of insolvency". Bradley et al (1984) concluded that the optimum leverage level of a company is set by the balance between tax benefit from liability, as against liability-concerned with costs. They display that firm leverage is inversely concerned with financial distress costs; greater non-debt tax shield decreases the corporation leverage level and firm leverage is inversely concerned with firm earning volatility owing to higher earnings volatility implying a higher present value of distress cost

Pecking Order Theory: This theory suggests that the primary source of finance for companies is firstly internal cash flow, then liability, and finally owners' equity (Myers, 1984). So, there is no ideal leverage level between the most and least favored of the dual categories of equity, which are equity and internal cash flow. Myers and Majluf (1984) provide several explanations to support their theory that firms favour internal cash flow to fund their investment. First, the cost of funds related to external sources, for example issuance charges and managerial costs, in addition to the under pricing of new securities. Second, the cost of not taking up a new project which may have a significant net present value, due to the cost of obtaining information about it, means that the company will not have to rely upon outside finance. Consequently, firms favour liability to equity when they need to seek external financing. Pecking Order theory forecasts a negative association between capital structure and profitability. The more profitable a company is, the greater its ability to rely upon its internal cash flow.

Agency Theory: One of the most important factors that affect a corporation's capital structure is the costs related to agency (Jensen and Meckling, 1976). One example is when the agent of a company seeks to maximize its own interests; such as if it makes use of the company's properties and assets for its own gain, then the company's owners will suppose that the agent will make decisions that could damage the corporation and its owners. Jensen and Meckling (1976) highlight the influence of external equity funding on agency costs, emphasizing that, when a corporation uses extensive exterior equity, then novel equity holders are willing to make supplementary payments for the services of a control agent. The charges connected with external equity funding are referred to as agency expenditures of equity. When a corporation uses liability funding, the agency costs associated are comprised of two costs which are monitoring and bankruptcy cost.

\section{Dividends Policy Theories}


One of the most important decisions made by the board of a company is announcing the paying of dividends. The directors need to be attentive and cautious when deciding upon the paying of dividends, and also the amount of those dividends. Several researchers have struggled to examine the key factors involved in dividend strategy, and construct theories based upon them. The key decisions to be made in relation to this issue include the characteristics of the firm and the structure of the market; since these are the main factors that have an impact on the firm's dividends policy.

Agency theory: Easterbrook (1984) debates whether dividends policy plays a main role in decreasing the complications between stockholders and the board of directors. Moreover, increasing dividends tend to decrease the amount of internal cash flow which executives may wish to allocate to finance innovative projects, and this will increase their reliance on exterior sources of capital. Jensen (1986) supports agency theory and arguing that this could be applied to an analysis of decreasing agency expenditures. Agency models forecast that dividend could help to decrease the difficulties associated with information asymmetry. Paying dividends can be a useful tool for decreasing levels of cash flow under board control, and therefore assist in keeping difficulties to a minimum (Bhaduri 2002).

Signalling theory: This theory suggests that the information available about how a corporation manages the transfer of dividends is a useful indication for market participants regarding the existing and forthcoming revenues of that corporation (e.g., Ambarish et al., 1987). Fuller and Blau (2010) have recognized that an important influence on a corporation's share returns are of variations in its dividends, and suggest that variations in dividend policy have an impact on the corporation's value. However, several studies have found very little evidence to support signalling theory ( $\mathrm{Li}$ and Zhao, 2008; Brav et al., 2005). Shareholders may respond positively or negatively to such declarations of dividend. Consequently, the declaration of liability funding could be viewed as a positive sign to stockholders and investors may view this liability issuance to be an indication of a respectable financial policy; and company executives may not wish outsiders to interfere with what is effectively prospective revenue (Koch and Shenoy 1999).

Lifecycle Theory: This theory proposes that mature companies are in an advantageous position for paying dividends as they have gathered a strong internal cash flow as well as having secure opportunities for outside funding (De Angelo et al., 2006). The lifecycle period of a corporation provides a good indication of that company's capability to pay dividends. Based on this theory, a corporation has numerous investment opportunities, external funding is advantageous, and in addition company profitability is good. Fama and French (2001) argue that companies with low income and which have few opportunities for investment tend to pay lower dividends. De Angelo et al (2006) suggest that earnings that are retained and kept as reserves as part of the corporation's lifecycle, will provide the company with a greater opportunity for paying dividends.

\section{Literature Reviews}

\section{Capital Structure}

Bennett and Donnelly (1993) studied the factors behind the decisions of leverage strategy in the UK corporations. They found significant positive associations between TA and capital structure. Rajan and Zingales (1995) investigated the main factors behind the capital structure of companies across Italy, Japan, UK, Canada, Germany, France and USA. They found that leverage has a significant relationship with tangibility and firm size, as well as finding a negative association with growth opportunities (GO). Ozkan 
(2001) finds a negative association reported by the UK firms between GO; liquidity and profitability with leverage, whereas size have a positive link with capital structure. Furthermore, Antoniou et al (2008) investigate data from banks and countries, regarding the leverage choices independent of the market, and debate that legal and financial systems have an impact on companies' capital structure opportunities. The outcomes show that profitability is negatively associated with leverage in the all countries with the exception of Japan as well as leverage and GO are negatively associated in all countries except for USA. Viviani (2008) explain the leverage of French wine companies and find a negative and significant coefficient for profitability; GO; TA.

Investigation of the available choices regarding capital structure is a useful tool when looking at the diversity of emerging markets. Trade-off theory's forecast of the tax benefit obtained through leverage has been studied thoroughly by Al-Sakran (2001), who studied firms that did business in KSA. Al-Sakran found no association between liability percentage and tax, and that corporations did not gain any advantage from using leverage to decrease Zakat. Moreover; he found a significant correlation between leverage and the level of government ownership. Several researchers investigate the main factors behind the capital structure in developing countries For instance, Gonenc (2003) for Turkish firms; Pandey and Chotigeat (2004) based on Malaysian firms and Yu and Aquino (2009) for Philippine firms. In Thailand, the outcomes display that GO, profitability, and size are negatively associated with leverage, although tangibility is significantly linked (Wiwattanakantang, 1999). Gonenc (2003) finds a negative association between GO and leverage, whereas there is insignificant association for Malaysian firms. Caglayan and Sak (2010) find a significant positive link regarding Turkish banks. Eldomiaty (2007) examining the determinants of corporate leverage in Egypt according to the assumptions of trade-off, pecking order, and free cash flow theory. The results indicate that trade-off related determinants of capital structure are taxes, debt/equity ratio and bankruptcy risk; the pecking order-related determinants of capital structure are growth and profitability. Chadha and Sharma (2015) study the key determinants of capital structure for Indian manufacturing firms and which theory implications. It was empirically found that size; age; TA; growth; profitability is significantly correlated with the firm financial leverage.

\section{Dividends Policy}

There is a strong indication that corporation characteristics play a significant part in defining whether a company pays dividends or not (Fama and French, 2001). Barclay et al (1995) found that firms in the UK with opportunities for extraordinarily good investment have a comparatively subordinate dividend policy. They found, moreover, an important negative association with GO and a positive link with size. Denis and Osobov (2008) who were concerned with companies across the EU and Renneboog and Trojanowski (2010) studied UK companies. Chay and Suh (2009) demonstrate that added capital has a significant influence on sum of dividends. Coulton and Ruddock (2011) examined the dividends policy based on firms in Australia, and found that the profitability and size have a positive effect on the dividends policy, although GO have a significant but negative influence on dividend choices. Naceur et al (2006) studied Tunisian companies, and Huang et al (2010) studied Chinese corporations. These studies found a negative association between dividend and unpredictability of earnings; this indicates that companies which have unstable levels of earnings favour not paying dividends. A comparable examination based on Huang et al (2010) shows that similar policies are adopted by non-financial companies operating in China. Aivazian et al (2003) examined the foremost factors for dividend strategy in emerging markets. The results obtained were different to the results found from developed markets. They reflected that the influence of 
size, tangibility, risk, probability, GO, and leverage have a significant effect on dividend policy across eight emerging markets. Based on this literature, investigating the main factors behind the decisions of capital structure as well as dividends policy; it can be concluded that most of these studies mainly focused on developed countries rather than developing ones. However, a few studies are dealt with this issue in KSA. Few of these studies test both leverage and dividends together, and neither do they test the interrelationship between leverage and dividends; which this study intends to do in order to fill this gap.

\section{Developments of Hypotheses}

\subsection{Determinants of Capital Structure}

Tangible Assets (TA)

A corporation's tangible assets should be viewed as a positive influence upon its leverage; as these assets can be used as a guarantee for loans (Friend \& Lang, 1988). Jensen et al (1992) provide concrete evidence for the positive influence on leverage of guaranteed assets. According to agency theory; stockholders of leveraged firms are ready to sub-optimally finance that company, by appropriating wealth from bondholders (Titman and Wessels 1988). Agency and trade off theory posit a significant relation between capital structure and TA (Frank and Goyal, 2008). This outcome complies with Flannery and Rangan (2006). Rajan and Zingales (1995) mentioned that TA is calculated according to a percentage of the book value of tangible fixed assets, in relation to the book value of total assets. The leverage of a corporation mirrors its corporate risk. Companies with greater leverage face a greater risk of insolvency or bankruptcy. However, higher leverage is commonly linked with a greater level of TA.

\section{H1: There is a positive association between leverage and tangible assets.}

\section{Company Size}

The trade-off theory declares that very large companies have greater leverage than small companies. Based on pecking order theory, major companies tend to prefer equity to debt and therefore have lower leverage. Antoniou et al (2008) stated that corporation size is most frequently measured based on the logarithm of book value of total assets. The reasons for the success of large companies include the opportunity for continued expansion, and the minimal risk of insolvency (Titman and Wessels 1988). According to trade-off theory, the cost of lending will be less for large corporations. However, pecking order theory forecasts a negative relationship between capital structure and size, as very large corporations have a decent reputation and have an extensive connection with finance providers as banks, decreasing the problem of facing opposition to loans. Consequently, large companies will be able to increase equity from the market at minimal cost. A corporation's size has been found to have a significant effect on capital structure (e.g. Antoniou et al., 2008; Hovakimian et al., 2004).

\section{H2: Firm size has a positive effect on leverage.}

\section{Growth Opportunities (GO)}

Theoretical disagreement continues concerning the relationship between GO and leverage. Companies with high levels of GO tend to have minimal free cash-flow difficulties, and are able to easily absorb any costs resulting from their debts. According to Trade-off theory, corporation leverage declines as GO increase. Based on agency theory, firms with high GO' are more likely to suffer from conflicts of interest between their stockholders and their debt holders during periods of financial distress, resulting in a high agency cost of debt. Myers (1977) argues that, the sum total of debt issued will be 
negatively associated with GO. Trade off theory predicts an inverse association, as the significance of GO will be low where corporations head towards insolvency (Gaud et al., 2005). Titman and Wessels (1988) found that the predictable growth percentage should be seen as being negatively related to leverage. Gaud et al (2005); Frank and Goyal (2003) find a negative association, while Pandey and Chotigeat (2004); Chen (2004) find a positive association. We suppose there is a negative link between CG and leverage. GO are calculated based on market to book ratio of equity as adopted by Cleary (1999); Gonenc (2003).

\section{H3: There is a negative association between leverage and growth opportunities.}

\section{Liquidity}

Greater liquidity sustains a corporation by enabling it to fund its investment using internal funds, as well as reducing its level of liability (Ozkan, 2001). Consequently, it can be assumed that there is a negative association between liquidity and leverage. Firms with substantial liquid assets have the ability to utilize their assets for funding their investments. Al-Najjar (2011) argues that a corporation's liquidity situation should have a negative influence on leverage proportion. Furthermore, Myers and Rajan (1998) claim that when there are exceptional agency charges of liquidity, external creditors will limit the sum of liability funding that the corporation will be able to obtain.

\section{H4: There is a negative association between leverage and liquidity.}

\section{Profitability}

According to agency theory, when profitable firms face severe free cash-flow difficulties, they will need higher leverage in order to avoid the possibility of administration. On the other hand, pecking order theory suggests that firms that have high levels of profitability become less levered over time, because they have internal finances which can be used to fund investment and are less likely to seek liability financing. Companies would tend to follow a funding pattern that channels diverse sources of finance to a specific purpose. They will favour internal funding options over the external options, and then would issue obligation if such low-cost substitutes are exhausted. Profitable companies are expected to have additional retained earnings. We suppose a negative association between leverage and profitability ratio (e.g. Chang and Dasgupta, 2009). This study follows Lemmon et al (2008); Leary and Roberts (2005) who calculated profitability based on net operating income over book value of total assets.

\section{H5: There is a negative association between leverage and profitability.}

\section{Dividend}

The dividend is an additional element that may have an impact upon a corporation's leverage. Based on the agency theory perspective, firms with an exceptional proportion of dividends will have subordinate agency charges of equity, and this may motivate companies to employ more equity funding (Rozeff, 1982). There is an opposite association when firms paying dividends may appear to be giving an indication of a future increase in income, and this can lead to a reduction in the cost of equity (Antoniou et al., 2008). The study calculated dividend pay-out percentage based on the proportion of dividends to net income which I adopt in this study.

\section{H6: The dividend pay-out ratio inversely influence on leverage.}




\section{Life Cycle}

Life-cycle theory is adopted in order to clarify the relationship between leverage and life cycle (De Angelo et al., 2006; Grullon and Michaely, 2002). This is based upon the manner of trade-offs between paybacks (e.g. savings in cost of flotation) and costs (e.g. agency charges of free cash flow) of leverage.

\section{H7: There is a positive correlation between Life Cycle of firm and leverage.}

\subsection{Determinants of dividend policy \\ Profitability}

The greater a company's profitability, the greater the amount of funds available to the directors to invest; consequently, this study assumes that a corporation's increased earnings will increase its ability to pay dividends and minimize the agency charges of free cash flow, as projected by Jensen (1986). Pecking order theory supports that association between dividend and profitability, showing that firms' funding investment opportunities are in a specific order: firstly, primary with retained earnings; secondly, from liability funding; and finally, from the issue of shares (Myers and Majluf, 1984). When the charges of issuing bonds in addition to equity are measured, less profitable companies are less likely to pay dividends. Consequently, highly profitable companies find it important to pay dividends, and are also able to save their profits as retained earnings. This outcome is also in agreement with signalling theory (Al-Najjar and Hussainey, 2009). Therefore, companies with exceptional profitability show a greater likelihood to pay dividends, as supported by Brockman and Unlu (2009), Denis and Osobov (2008). This study adopts net operating income divided by total assets for measuring profitability (Coulton and Ruddock, 2011).

\section{H1: There is a positive relationship between dividend and profitability.}

\section{Growth Opportunities (GO)}

Companies with extraordinary GO levels tend to have a subordinate dividend ratio since new investment will use huge amounts of internal funds, which has a lower cost than outside finance. Firms with high GO are able to use their internal cash flows profitably, and consequently pay smaller dividends. Myers and Majluf (1984) claim that a company's investment strategy will have a significant impact on the dividend policy, as the charges related to exterior sources of funding will generate a conflict between issuing of dividend and investment. The previous discussion is matched with Fuller and Blau (2010); Chay and Suh (2009); Ferris et al (2009). Chang and Rhee (1990) argue that the higher GO, the greater need to invest in future growth, and the greater the need to retain profits instead of paying dividends. It is similarly worth observing that pecking order theory supports this association between GO and dividend strategy. Based on Chay and Suh (2009); Naceur et al (2006), market value over book value of equity is adopted for measuring GO.

\section{H2: There is a negative association between dividend and growth opportunities.}

\section{Firm Size}

Fama and French (2001) display that very large companies are more likely to pay supplementary dividends compared to minor companies. They demonstrate that the overall assets of firms that pay high dividends are more than eight times that of non-paying firms. Several researchers propose that large companies have greater access to capital markets because they are well known, have established relationships with stockholders, are more differentiated, and have a smaller risk of insolvency and therefore; the cost of 
exterior finance will be lower for these firms (Brockman and Unlu, 2009, Eije and Megginson, 2008; Denis and Osobov, 2008). In large companies, stockholders will seek to decrease agency charges of free cash flow by encouraging companies to pay dividends, thus furthering the collaboration between the company's board and the capital market. In this study, we use the natural logarithm of book value of total assets for measuring compaction size as suggested by Barclay et al. (2009); Gugler and Yurtoglu (2003).

\section{H3: There is a positive association between dividends and size .}

\section{Tangible Assets (TA)}

Aivazian et al (2003) claim that with more TA, there is less obtainability of short-term assets for corporations to borrow, which leads to compulsory financial limitations on companies' processes in financial systems in which the foremost source of liability is short-term funding. Consequently, less TA, the more protected the short-term funding and the fewer conflicts with agencies and more ability to pay more dividends.

\section{H4: There is a negative association between dividend and tangible assets.}

\section{Life Cycle (LC)}

Life-cycle theory is used to clarify the variation of divided between firms based on the difference between the benefits and costs of paying dividends (Denis and Osobov, 2008; De Angelo et al., 2006). The charges as well as the paybacks are not comparable between individual firms. Owing to decreasing investment chances and accretion of undistributed revenue, developed companies find that the paying of dividends is necessary while newer companies need to build up reserves to fund GO, and therefore need to retain their incomes. We use the percentage of retained earnings in proportion to common equity as a representation of corporation maturity or LC (De Angelo et al., 2006).

H5: There is a positive relationship between the life cycle and dividend.

\section{Liquidity}

A company's liquidity has a significant effect on the company's decisions regarding the payment of cash dividends. This positive relationship agrees with previous studies and with signalling theory $(\mathrm{Ho}, 2003)$. Liquidity has an important impact on dividend strategy. It is claimed that companies with greater accessibility to funds are more likely to pay dividends than are companies with limited funds (Al-Najjar, 2011).

\section{H6. There is a positive association between dividend and liquidity.}

\section{Leverage}

Agency theory suggests that dividend and leverage may decrease the difficulties related to information asymmetry and they work as a mechanism for lessening the cash flow under board control, and also assist in moderating agency complications. Aivazian et al (2003); Jensen et al (1992) suggest that a corporation's leverage is a main determinant in indicating what the business's decision to pay dividend will be. This principle is consistent with the agency costs theory. Chang and Rhee (1990) concluded that there is a positive link between leverage and dividend strategy, and proposed that companies are borrowing in order to pay dividends. This supports signalling theory, as it has the effect of providing trustworthy news information for stockholders regarding the company's future forecasts.

\section{H7. There is an association between leverage and dividend.}

\subsection{The interrelationship between dividend policy and capital structure}


Dividend strategy is regarded as one of the factors of leverage. Companies with a good reputation for paying dividends are less likely to be the subject of conflicting reports, and can therefore access equity in the marketplace. Bhaduri (2002) argues that dividend signifies an indication of enhanced financial health, and therefore of greater debt-issuing capacity which supported by the signalling theory. Therefore, a significant association is predictable between dividend and leverage. Moreover, leverage is also represented as one of most significant factors of dividend policy. The practical modelling of leverage and dividend strategy shares a roughly similar set of causative variables. Al-Najjar (2011) examines the inter-association between leverage and dividend strategy in developing markets, by studying the Jordanian market. He found that determinants of dividend plan and capital structure share a similar set of recommended elements.

The inter-association between dividends and capital structure is supported by two arguments. First, dividend and capital structure are affected by similar market inadequacies, as agency theory and signalling theory suggest. Second, capital structure and dividend policy interrelates, and therefore any issue that adversely effects on will affect the other (Chaplinsky and Niehaus 1993). The agency model predicts that use of liability funding and dividend can work as a mechanism to challenge any problems arising from the situation of the agency. Based on Bhaduri (2002); Easterbrook (1984), both dividend policy and leverage can reduce the cash flow which is controlled by the board of directors. Jensen (1986) clarifies that paying dividend has a positive impact on the issue of the agency by decreasing surplus cash flow in the company. Signalling theory clarifies that a corporation which pays further dividends delivers a message about its robust financial performance that raises the credit standing of corporation. Furthermore, dividends issued by declining firms can cause an "information gap" between directors and stockholders. As these companies may increase supplementary liability, their dividend is determined by leverage ratios. Consequently; based on these principles, it can be argued that there is a positive association between dividend ratios and capital structure. However, leverage is a negative factor of dividend where companies with more liability choose to repay existing loans instead of paying higher dividends. Leveraged companies have a higher risk of financial distress, and this risk may result in a lower level of dividend (Patra et al., 2012; Al-Najjar, 2009; Al-Malkawi, 2007).

\section{Data and Methodology}

Data was collected from Bloomberg and DataStream throughout the period of the study, between 2012 and 2016. Based on these datasets, companies were chosen that had produced annual reports during this period without noteworthy gaps. Therefore, a sample of 91 non-financial KSA corporations from eight different sectors is included in the analysis. This sample comprises essentially non-financial firms; the research therefore excluded financial firms such as banks, which exhibit different characteristics.

\section{Regression Model}

\section{Regressions model (1): Capital structure}

An enormous body of capital structure research makes use of ordinary least square (OLS) estimates with panel data to investigate theories related to capital structure (e.g. Degryse et al., 2012; Qureshi, 2010; Bharath et al., 2009). The study uses the following model:

$$
\mathbf{L E V}_{\text {it }}=\alpha+\mathbf{X}_{\text {it }}+\varepsilon \quad \text { Model (1) }
$$

Where the dependent variable (Lev it) is (total debt-to-equity ratio), $\boldsymbol{\alpha}$ is the intercept, $\mathbf{X}$ it is the column vector of financial variables related to determinants for capital structure for firm $\mathbf{i}$ at time $\mathbf{t}$

Based on the previous model, the main details model is as follows: 


$$
\begin{aligned}
& \mathrm{LEV}_{\text {it }}=\alpha+\beta_{1} \text { TAN }_{\text {it }}+\beta_{2} \text { SIZ }_{\text {it }}+\beta_{3} \frac{\text { M }}{B_{i t}}+\beta_{4} \text { LIFE }_{i t}+\beta_{5} L_{\text {it }}+\beta_{6} \text { PRO }_{i t}+ \\
& \beta_{7} \text { DIV }_{i t}+\beta_{8} \text { LAGG }_{i t}+\varepsilon \quad \text { Model (2) }
\end{aligned}
$$

Where: LEV; Leverage it is the ratio of total debt to total book value of assets, where total debt is measured by total liabilities minus accounts payable and other liabilities. TAN it (asset tangibility) is the ratio of the book value of tangible fixed assets to the book value of total assets. SZ it (firm size) is the natural log of total assets. (M/B) it (growth opportunities) is measured by the ratio of the market to book value of equity. LQ it (liquidity) is measured by the ratio of current assets to current liabilities. PR it (profitability) is the ratio of net operating income to the book value of total assets. DIV it (dividend pay-out ratio) is the ratio of dividends to net income. LIFE is the life cycle Ratio between retained earnings to common equity; LAGG is the lagged dividends which are last year dividends. ( $\boldsymbol{\alpha})$ Is the intercept. ( $\boldsymbol{\varepsilon}$ ) It is the residual error for Firm i at Year t.

\section{Regression model (2): dividends policy}

A large body of dividend studies use logistic regression (LR) estimates to test dividends policy. We adopted LR as our dependent variable, with dividends measured as a dummy variable (I if the firm pays dividends and 0 otherwise). We investigate the main determinants of dividends:

$$
\text { DIV }_{\text {it }}=\alpha+\mathbf{X}_{\text {it }}+\varepsilon \quad \operatorname{Model}(3)
$$

Where the dependent variable (DIV it) is (dummy variable), $\boldsymbol{\alpha}$ is the intercept, $\mathrm{X}$ it is the column vector of dividends variables related to determinants for dividends policy for firm $\mathbf{i}$ at time $\mathbf{t}$

Based on the previous model; the main details model as following:

$$
\begin{gathered}
\text { DIVI }_{\text {it }}=\alpha+\beta_{1} \text { TAN }_{\text {it }}+\beta_{2} \text { SIZ }_{\text {it }}+\beta_{3} \frac{\text { M }}{B_{i t}}+\beta_{4} \text { LIFE }_{i t}+\beta_{5} L_{i t}+\beta_{6} \text { PRO }_{i t}+ \\
\beta_{7} \text { LEV }_{\text {it }}+\beta_{8} \text { LAGG }_{\text {it }}+\varepsilon \quad \text { Model (4) }
\end{gathered}
$$

Where: DIVI; Dividends it is the ratio of dividends pay-out. TAN it (asset tangibility) is the ratio of the book value of tangible fixed assets to the book value of total assets. SZ it (firm size) is the natural log of total assets. (M/B) it (growth opportunities) is measured by the ratio of the market to book value of equity. LQ it (liquidity) is measured by the ratio of current assets to current liabilities. PR it (profitability) is the ratio of net operating income to the book value of total assets. LIFE it is the life cycle Ratio between retained earnings to common equity, LAGG is the lagged dividends which is last year dividends. LEV is measuring

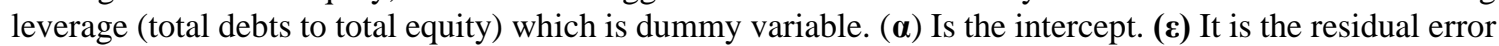
for Firm i at Year $\mathbf{t}$.

Definitions of variables and expected relationships for the whole variables related to the two models are presented in the table 1.

Table 1: Definitions of variables and expected relationships 


\begin{tabular}{|c|c|c|c|}
\hline \multicolumn{4}{|c|}{$\mathrm{LEV}_{\mathrm{it}}=\alpha+\beta_{1} \mathrm{TAN}_{\mathrm{it}}+\beta_{2} \mathrm{SIZ}_{\mathrm{it}}+\beta_{3} \frac{\mathrm{M}}{\mathrm{B}_{\mathrm{it}}}+\beta_{4} \mathrm{LIFE}_{\mathrm{it}}+\beta_{5} \mathrm{LQ}_{\mathrm{it}}+\beta_{6} \mathrm{PRO}_{\mathrm{it}}+\beta_{8} \mathrm{DIV}_{\mathrm{it}}+\beta_{8} \mathrm{LAGG}_{\mathrm{it}}+\mathrm{e}$} \\
\hline \multicolumn{4}{|c|}{$\mathrm{DIVI}_{\mathrm{it}}=\alpha+\beta_{1} \mathrm{TAN}_{\mathrm{it}}+\beta_{2} \mathrm{SIZ}_{\mathrm{it}}+\beta_{3} \frac{\mathrm{M}}{\mathrm{B}_{\mathrm{it}}}+\beta_{4} \mathrm{LIFE}_{\mathrm{it}}+\beta_{5} \mathrm{LQ}_{\mathrm{it}}+\beta_{6} \mathrm{PRO}_{\mathrm{it}}+\beta_{8} \mathrm{LEV}_{\mathrm{it}}+\beta_{8} \mathrm{LAGG}_{\mathrm{it}}+\mathrm{e}$} \\
\hline Variables & Symbol & Definition & Unit \\
\hline Leverage & LEV & Ratio of total debts to total equity & Ratio \\
\hline Dividend & DIV & It is a dummy variable ( 1 if the firm pay dividends and 0 otherwise) & Dummy \\
\hline Assets tangibility & TAN & Ratio of book value of tangible fixed assets to the book value of total assets & Ratio \\
\hline Firm size & SIZ & Natural log of total sales & Number \\
\hline $\begin{array}{l}\text { Growth } \\
\text { opportunities }\end{array}$ & $\frac{M}{B}$ & $\begin{array}{l}\text { Market to book ratio: Market value divided by book value of the firm at the } \\
\text { end of fiscal year }\end{array}$ & Ratio \\
\hline Life cycle & LIFE & Ratio between retained earnings to common equity & Ratio \\
\hline Liquidity & LIQ & Ratio of current assets to current liabilities & Ratio \\
\hline Profitability & PRO & Income before extraordinary items divided by total asset & Percentage \\
\hline $\begin{array}{l}\text { Lagged } \\
\text { dividends }\end{array}$ & LAGG & Lastyear dividends & Number \\
\hline \multicolumn{4}{|c|}{$\begin{array}{l}\text { LEV; Leverage it is the ratio of total debt to total book value of equity, where total debt is measured by total liabilities. TAN it (asset } \\
\text { tangibility) is the ratio of the bookvalue of tangible fixed assets to the book value of total assets. SIZit (firm size) is the natural log of total } \\
\text { assets (M/B) it (growth opportunities) is measured by the ratio of the market to bookvalue of equity. LIQ it (liquidity) is measured by the } \\
\text { ratio of current assets to current liabilities. PRO it (profitability) is the ratio of net operating income to the book value of total assets. DIV } \\
\text { it (dividend pay-out ratio) is the ratio of dividends to net income. LIFE it is the life cycle Ratio between retained earnings to common } \\
\text { equity. LAGG is the lagged dividends which is lastyear dividends. }(\alpha) \text { Is the intercept. }(\varepsilon) \text { It is the residual error for Firm } i \text { at Year } t\end{array}$} \\
\hline
\end{tabular}

\section{Empirical Analysis}

Table 2 shows the descriptive statistics for our sample. It reveals a very low leverage ratio: on average, KSA companies have $20.06 \%$, with a maximum $69 \%$. Moreover, the table shows that on average, most of the corporations in our sample are profitable, as the ratio of net operating income is 15.46. As well, most of the companies do not have liquidity difficulties, as the liquidity ratio mean is 2.40 . This indicates that companies in this study have a requirement to meet their obligation to security holders, which affects their decision to pay dividends. The table also shows that tangibility assets for the selected firms are 0.61 , whereas life cycle is 0.27 .

Table 2: Descriptive statistics of dependent and independent variables

\begin{tabular}{|l|c|c|c|c|c|}
\hline & $\mathbf{N}$ & Minimum & Maximum & Mean & Std. Deviation \\
\hline LEV & 545 & 0 & 69 & 20.06 & 17.464 \\
\hline DPO & 545 & 0 & 1 & 0.79 & 0.406 \\
\hline LIQ & 545 & 0 & 14 & 2.40 & 1.854 \\
\hline SIZE & 545 & 5 & 9 & 6.38 & 0.699 \\
\hline PRO & 545 & -25 & 61 & 15.46 & 12.486 \\
\hline TANG & 545 & 0 & 1 & 0.61 & 0.192 \\
\hline MBTV & 545 & 1 & 22 & 2.86 & 1.966 \\
\hline LIFE & 545 & 0 & 1 & 0.27 & 0.174 \\
\hline LAGG & 545 & 0 & 18 & 1.26 & 1.587 \\
\hline
\end{tabular}

\subsection{Model (1): Capital structure results Correlation matrix}

Table 3 displays the correlation coefficients between the variables. The table shows that the association between variables is accepted, which indicates that there is no noteworthy collinearity problem. Debt is negatively associated with dividend payments, growth opportunities, liquidity and lagged dividends. Furthermore, the correlation matrix shows 
a positive association between leverage and size of firm, life cycle and asset tangibility, whereas there is no association between leverage and profitability. This result reflects the notion that large companies make more use of liability financing, possibly due to their superior entry to credit markets. Furthermore, debt is negatively associated with liquidity, suggesting that companies employ internal cash flow to fund investments. Debt and dividend pay-out ratio are negatively associated, demonstrating that companies that pay dividends are less reliant on liability.

Table 3: Correlation matrix

\begin{tabular}{|c|c|c|c|c|c|c|c|c|c|}
\hline & LEV & DP0 & LIQ & SIZE & PR0 & TANG & MBTV & LIFE & LAGG \\
\hline LEV & 1 & & & & & & & & \\
\hline DP0 & $-0.089^{*}$ & 1 & & & & & & & \\
\hline LIQ & $-0.427^{* *}$ & -0.069 & 1 & & & & & & \\
\hline SIZE & $0.456^{* *}$ & $0.142^{* *}$ & $-0.209^{\prime \prime}$ & 1 & & & & & \\
\hline PR0 & -0.069 & $0.297^{\prime \prime}$ & -0.041 & $0.122^{=}$ & 1 & & & & \\
\hline TANG & $0.088^{*}$ & -0.005 & $-0.248^{\prime \prime}$ & $0.296^{*}$ & $-0.109^{2}$ & 1 & & & \\
\hline MBTV & $-0.124^{+\pi}$ & -0.034 & -0.048 & $-0.167^{*}$ & $0.433^{* 1}$ & $-0.152^{=*}$ & 1 & & \\
\hline LIFE & $0.140^{* *}$ & $0.278^{=1}$ & $-0.116^{=}$ & $0.176^{=}$ & $0.374^{*}$ & -0.079 & 0.077 & 1 & \\
\hline LAGG & $-0.186^{4 *}$ & $0.353^{=}$ & 0.080 & $0.203^{-1}$ & $0.495^{-1}$ & 0.000 & $0.247^{+*}$ & $0.292^{-1}$ & 1 \\
\hline
\end{tabular}

\section{Regression Analysis (OLS Analysis)}

Table 4 shows the results of the coefficients analysis. Multicollinearity poses a problem when a number of explanatory variables are employed. To measure multicollinearity, the variance inflation factor (VIF) was used. Multicollinearity is considered as significant when the VIF exceeds 10. The results of the two panels (table 4) show that the VIF is less than 10, which means that there is no multicollinearity problem (Acock, 2008). Harris and Raviv (1990); Titman and Wessels (1988) suggest that tangibility could be one of the main factors that define a company's obligation levels. The outcomes of the analysis show that there is a negative association between asset tangibility and capital structure. This result challenges the positive predictive indication in previous literature, where a tangibility asset may be deliberated like guarantees. However, this outcome may be due to the fact that managers are opposed to insolvency because of its negative effect on their recompense strategies as well as their job safety. Consequently, corporations with lower tangible assets may tend to use more liability to direct executive activity regardless of the charge of issuing liability. Therefore, there is a balance between agency costs and cost of debt; we therefore suppose a negative association between tangible assets and leverage (Bhaduri, 2002). Based on agency theory, corporations undertake liability to decrease agency costs, and tangible assets are used to secure more liability. This argument is supported by Titman and Wessels (1988). So, we rejected hypothesis H1, which supposes a negative association.

A positive association is found between capital structure and firm size, which supports hypothesis H2. Huang and Song (2006); Voulgaris et al (2004); Cassar and Holmes (2003) report comparable results. This outcome is in keeping with transaction cost theory, which specifies that large corporations tend to be more extensive and have a greater ability to enter the liability funding market. A large Company is less likely to suffer financial distress and therefore has the capability to take on more debt; there is therefore a positive link between size and leverage. Consequently, large KSA companies are less liable to 
undergo economic hardship and are therefore more capable of securing liability funding. The analysis shows a positive insignificant relationship between growth opportunities and capital structure. This insignificant link correlates with the findings of Bevan and Danbolt (2002), Bennett and Donnelly (1993). This result does not support agency theory, which posits that agency complications are more severe for corporations in developing nations, as agencies are more stringent in their selection of investments in these countries. Therefore, predictable growth rates should be negatively linked with long-term leverage (Titman and Wessels, 1988). The study thus rejects hypothesis H3.

The correlation coefficient association between capital structure and liquidity is negative. This conclusion is supported by Myers (1977), who argues that as underinvestment may be problematic, corporations tend to borrow on a short-term basis. Corporations with more liquid assets can use these assets to fund forthcoming investments. A company's liquidity position will therefore have a negative effect on its capital structure. A further argument for a negative association is provided by Myers and Rajan (1998), who posit that when agency costs relating to liquidity are high, external creditors will limit the liability funding available to the corporation. This theory states that companies with higher liquidity will be able fund their operations without taking on further liability. The negative link has been demonstrated by numerous researchers carrying out similar studies. Amidu and Abor (2006) also found a negative association between the two variables. Therefore, we accept hypothesis H4. With regard to the link between capital structure and profitability, the analysis shows an insignificant association, with a negative link between the two variables. This result is consistent with Long and Malitz (1986), who found no link between capital structure and profitability. Several theoretical studies have been carried out since the work of Modigliani and Miller (1958), and no consistent link has been found between profitability and capital structure. Based on pecking order theory, we anticipated a negative association between profitability and leverage. The regression outcomes showed this to be true, but with an insignificant association. We thus reject hypothesis H5.

With regard to the link between capital structure and dividends, the analysis shows no evidence that dividends affect a corporation's debt ratio. This correlation is supported by Antoniou et al (2008). Rozeff (1982) argues that based on agency and transaction costs, corporations with extraordinary dividend payments will have subordinate agency costs relating to equity, which may lead companies to employ more equity funding. So, we reject hypothesis H6. The analysis of the relationship between capital structure and life cycle payments shows an insignificant relationship. This result is in line with Grullon and Michaely (2002). Consequently, we reject hypothesis H7.

Table 4: Coefficients analysis 


\begin{tabular}{|l|c|c|c|c|c|c|c|}
\hline \multirow{2}{*}{ Model } & \multicolumn{2}{|c|}{$\begin{array}{c}\text { Unstandardized } \\
\text { Coefficients }\end{array}$} & $\begin{array}{c}\text { Standardized } \\
\text { Coefficients }\end{array}$ & \multirow{2}{*}{ T } & \multirow{2}{*}{ Sig } & \multicolumn{2}{|c|}{$\begin{array}{c}\text { Collinearity } \\
\text { Statistics }\end{array}$} \\
\cline { 2 - 5 } \cline { 6 - 8 } & $\mathrm{B}$ & Std. Error & Beta & & & Tolerance & VIF \\
\hline (Constant) & -37.575 & 6.639 & & -5.660 & 0.000 & & \\
\hline DPO & -2.548 & 1.558 & -0.059 & -1.636 & 0.103 & 0.667 & 1.500 \\
\hline LIQ & -3.825 & 0.311 & -0.406 & -12.294 & 0.000 & 0.801 & 1.249 \\
\hline SIZE & 12.740 & 0.991 & $\mathbf{0 . 5 1 0}$ & 12.855 & $\mathbf{0 . 0 0 0}$ & 0.555 & 1.802 \\
\hline PRO & -0.092 & 0.058 & -0.066 & -1.579 & 0.115 & 0.504 & 1.983 \\
\hline TANG & -9.322 & 2.994 & -0.103 & -3.114 & 0.002 & 0.805 & 1.243 \\
\hline MBTV & 0.144 & 0.338 & 0.016 & 0.425 & 0.671 & 0.603 & 1.659 \\
\hline LIFE & 5.001 & 4.011 & 0.050 & 1.247 & 0.213 & 0.549 & 1.823 \\
\hline LAGG & -2.539 & 0.426 & -0.231 & -5.960 & $\mathbf{0 . 0 0 0}$ & 0.583 & 1.714 \\
\hline Model Summary & & & & & & \\
Adjusted R Square & 0.525 & & & & & \\
F & 25.030 & & & & & \\
Sig & 0.000 & & & & & \\
Durbin-Watson & 0.648 & & & & & & \\
\hline
\end{tabular}

\subsection{Model 2: Dividend Results}

\section{Block 0: Beginning Block}

Table 5 shows that the total number of observations is 545. By dividing the total observations by the number of variables (8), the minimum ideal sample number should be 68 firms. This study's sample includes 90 firms, which is an appropriate size. The model of Block 0 shows an association between dividends and firm size, profitability, tangibility, liquidity and lagged dividend.

Table 5: Result of Block 0

\begin{tabular}{|c|c|c|c|c|c|}
\hline & & & Score & $d f$ & Sig \\
\hline \multirow[t]{9}{*}{ Step 0} & \multirow[t]{8}{*}{ Variables } & Leverage & 2.632 & 1 & 0.105 \\
\hline & & Firm Size & 4.322 & 1 & 0.038 \\
\hline & & Profitability & 10.941 & 1 & 0.001 \\
\hline & & Tangibility & 48.053 & 1 & 0.000 \\
\hline & & MBTV & .013 & 1 & 0.910 \\
\hline & & Life cycle & .616 & 1 & 0.432 \\
\hline & & Lagged dividend & 42.209 & 1 & 0.000 \\
\hline & & Liquidity & 67.806 & 1 & 0.000 \\
\hline & \multicolumn{2}{|c|}{ Overall Statistics } & 120.138 & 8 & 0.000 \\
\hline & \multicolumn{2}{|c|}{$\begin{array}{l}\text { Variables in the Equation } \\
\text { Wald } \\
\text { Sig } \\
\text { Total number of observations }\end{array}$} & $\begin{array}{c}161.082 \\
0.000 \\
545\end{array}$ & & \\
\hline
\end{tabular}




\section{Block 1: Method = Enter}

The analysis shows an overall percentage correct of $93.3 \%$. Compared with Block 0 , this model is accurate and perfect. It also shows that the model is significant $(0.000)$. The $\mathrm{R}$ square is $0.524 \%$. The model of Block 1 shows an association between dividends and firm size, tangibility, life cycle and Liquidity.

Table 6: Result of Block 1

\begin{tabular}{|c|c|c|c|c|c|c|c|c|}
\hline \multicolumn{9}{|c|}{ Variables in the Equation } \\
\hline & & B & S.E & \multirow{2}{*}{\multicolumn{2}{|c|}{2.166}} & df & Sig & $\operatorname{Exp}(B)$ \\
\hline \multirow[t]{9}{*}{ Step 1} & Liquidity & -0.112 & 0.076 & & & 1 & 0.141 & 0.894 \\
\hline & Firm Size & -0.018 & 0.010 & \multicolumn{2}{|c|}{3.276} & 1 & 0.070 & 0.982 \\
\hline & Profitability & 0.194 & 0.284 & \multicolumn{2}{|c|}{0.465} & 1 & 0.495 & 1.214 \\
\hline & Tangibility & 0.037 & 00.016 & \multicolumn{2}{|c|}{5.481} & 1 & 0.019 & 1.038 \\
\hline & MBTV & -0.453 & 0.774 & \multicolumn{2}{|c|}{0.342} & 1 & 0.559 & 0.636 \\
\hline & Life cycle & -0.265 & 0.095 & \multicolumn{2}{|c|}{7.731} & 1 & 0.005 & 0.767 \\
\hline & Lagged & 1.778 & 1.144 & \multicolumn{2}{|c|}{2.417} & 1 & 0.120 & 5.916 \\
\hline & Liquidity & 2.917 & 0.385 & \multicolumn{2}{|c|}{57.297} & 1 & 0.000 & 18.483 \\
\hline & Constant & -0.557 & 1.669 & \multicolumn{2}{|c|}{0.112} & 1 & 0.738 & 0.573 \\
\hline \multicolumn{9}{|c|}{ Omnibus Tests of Model Coefficationts } \\
\hline Step 1 & \multirow{2}{*}{\multicolumn{2}{|c|}{ Step }} & \multicolumn{2}{|c|}{ Chi-square } & \multicolumn{3}{|c|}{ Df } & Sig. \\
\hline Step 1 & & & \multicolumn{2}{|c|}{222.392} & \multicolumn{3}{|c|}{8} & 0.000 \\
\hline 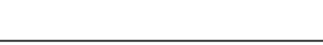 & \multicolumn{2}{|c|}{ Block } & $222.3 \mathrm{c}$ & & & 0.000 \\
\hline & \multicolumn{2}{|c|}{ Model } & \multicolumn{2}{|c|}{222.392} & & & & 0.000 \\
\hline \multirow[t]{2}{*}{$\begin{array}{l}\text { Model Summary } \\
\text { Step } 1\end{array}$} & \multicolumn{2}{|c|}{-2 log likelihood } & \multicolumn{2}{|c|}{$\begin{array}{l}\text { Cox \& snell R. } \\
\text { Square }\end{array}$} & \multicolumn{3}{|c|}{$\begin{array}{l}\text { Nagelkerke R. } \\
\text { Square }\end{array}$} & \\
\hline & \multicolumn{2}{|c|}{333.955} & \multicolumn{2}{|c|}{0.335} & \multicolumn{3}{|c|}{0.524} & \\
\hline
\end{tabular}

\section{Block 2: Method = Enter}

Table 7 shows R square of 0.596 . The overall percentage is $89.4 \%$, which is higher than Block 0 and Block 1. Compared with the result of $25 \%$ shown in Block 1, this model is an accurate and perfect means of explaining the determinants of dividend policy. Model Block 2 shows an association between dividends and profitability, MBTV and lagged dividends.

Table 7: Result of Block 2 


\begin{tabular}{|c|c|c|c|c|c|c|c|}
\hline \multicolumn{8}{|c|}{ Variables in the Equation } \\
\hline & & B & S.E & Wald & Df & Sig & $\operatorname{Exp}(B)$ \\
\hline \multirow[t]{8}{*}{ Step 1} & Leverage & -0.008 & 0.013 & 0.353 & 1 & 0.552 & 0.993 \\
\hline & Liquidity & -0.074 & 0.082 & 0.821 & 1 & 0.365 & 0.929 \\
\hline & Firm Size & 0.379 & 0.368 & 1.062 & 1 & 0.303 & 1.461 \\
\hline & Profitability & 0.044 & 0.018 & 60211 & 1 & 0.013 & 1.045 \\
\hline & Tangibility & -0.199 & 0.858 & 0.054 & 1 & 0.816 & 0.819 \\
\hline & MBTV & -0.206 & 0.093 & 4.880 & 1 & 0.027 & 0.814 \\
\hline & Life cycle & 1.379 & 1.296 & 1.132 & 1 & 0.287 & 3.970 \\
\hline & Lagged & 2.517 & 0.394 & 40.864 & 1 & 0.000 & 12.390 \\
\hline \multicolumn{8}{|c|}{ Omnibus Tests of Model Coefficients } \\
\hline & & Chi-square & $D f$ & Sig & & & \\
\hline \multirow[t]{3}{*}{ Step 1} & Step & 39.219 & 17 & .002 & & & \\
\hline & Block & 39.219 & 17 & .002 & & & \\
\hline & Model & 261.612 & 25 & .000 & & & \\
\hline \multirow{2}{*}{\multicolumn{2}{|c|}{$\begin{array}{l}\text { Model Summery } \\
\text { Step } 1\end{array}$}} & \multicolumn{2}{|c|}{-2 Log likelihood } & \multicolumn{2}{|c|}{$\begin{array}{l}\text { Cox \& Snell R } \\
\text { Square }\end{array}$} & $\begin{array}{c}\text { Nagelkerke } \\
\text { R Square }\end{array}$ & \\
\hline & & \multicolumn{2}{|c|}{294.735} & \multicolumn{2}{|c|}{0.381} & 0.596 & \\
\hline
\end{tabular}

\section{Logistic Analysis}

According to the results of model Block 2, shown in table 7 , there is a negative relationship between MBTV and dividends; there is a significant positive association between dividends and profitability and finally the analysis revealed a positive relationship between dividend policy and lagged dividends over the last year. An insignificant association is shown for other variables (leverage, liquidity, firm size, tangibility and life cycle). The association between dividends and growth opportunities (MBTV) is similar to the results of Fuller and Blau, (2010); Brockman and Unlu (2009) which found a negative link between the two variables. Ferreira and Vilela (2004) argue that companies with high growth opportunities may hold cash reserves in order to diminish financial costs. Furthermore, corporations with high investment opportunities may hold cash reserves in order to reduce the probability of missing upcoming opportunities. This outcome supports trade-off theory, which argues that firms set their optimal cash holdings by considering the balance between marginal paybacks and costs involved in holding liquid assets. When a firm has plans to expand, it will aim to reserve money for investment, which will have a negative impact on dividends. This result does not adhere to pecking order theory, which predicts that companies with high future growth opportunities will pay out lower dividends (Aggarwal and Kyaw, 2010). Therefore, we accept hypothesis $\mathrm{H} 2$.

With regard to the association between dividends and profitability, signalling theory proposes that profitability is positively correlated with dividend payments. More profitable firms will give positive indications to shareholders by issuing more dividends. This result adheres to established theory and is consistent with the findings of Aivazian et al (2003); Jensen et al (1992). According to Ross's (1977) signalling model, firms with high profitability will pay out more dividends as costly reliable indications. Based on these results, we accept hypothesis $\mathrm{H} 1$. Our research has found a negative but insignificant association between dividends and liquidity. A negative association was anticipated by Naceur et al (2006). In a more liquid market, where shares sell quickly, capital gains are preferred over dividends. Regression analysis found a positive insignificant association between dividends and size. Very large firms can simply increase their funds and support 
high dividend pay-outs as compared with small firms. This argument is supported by Patra et al (2012); Al-Najjar (2009), who support agency theory. We thus reject hypothesis H3.

The link between dividends and last-year dividends or lagged dividends is consistent with (Kania and Bacon, 2005). Rehman (2012) found that last-year dividends have a significant impact on contemporary period pay-outs, and that firms strive not to reduce dividend payments from previous years; instead they attempt to increase dividends. This result is in keeping with the findings of Pandey and Bhat (2007). With regard to the association between dividend policy and tangible assets, the analysis found an insignificant negative link. According to Aivazian et al (2003), in markets where the core source of funding is short-term liability, companies with more tangible assets pay fewer dividends than companies with lower tangible assets. Higher tangible assets correspond with fewer current assets and a lower probability that creditors will issue short-term loans. Therefore, higher tangible assets are correlated with a lower probability of dividend payouts. Finally, the regression analysis found a positive but insignificant link between dividends and life policy. This result is supported by life-cycle theory, which states that variations in dividend payments between corporations are based on their respective life cycles (Denis and Osobov, 2008).

\section{Conclusion}

This study seeks to contribute practical evidence to corporate finance literature by exploring two key subjects, namely, decisions relating to pay-outs (dividends) and policies relating to capital structure, in the context of developing markets in the KSA market. A sample of 91 non-financial KSA corporations was submitted to analysis. This study includes only the surviving companies for the period from 2011 to 2015 . The research adopts OLS to measure the determinants of capital structure and logistic regression to measure the determinants of dividend policy. This study found non-join determinant between dividends policy and capital structure.

\section{Capital structure}

This research investigates the primary influences affecting management decisions about the form of a company's capital structure. The study has constructed a model based on the main theories of capital structure, including trade-off, pecking order and agency cost theory, in order to clarify the association between company characteristics and leverage. Regression results from the first equation show that there is a positive relationship between firm size, based on total assets, and capital structure, based on leverage ratio. The analysis also found a negative link between leverage ratio and lagged dividends and between asset tangibility and liquidity. Finally, the analysis showed no significant association between leverage and any of the other variables (growth opportunities, profitability and life cycle). This result is in line with the arguments of trade-off theory. In summary, the results of agency theory and pecking order theory are applicable in KSA as a developing nation. Capital structure in KSA is therefore determined by a set of influences comparable to those developed and tested in developed markets.

\section{Dividend policy}

The research as well as investigates the key features affecting companies' decisions relating to dividend policy. This study has employed a model based on key dividend theories (lifecycle theory, signalling theory and agency theory). With regard to the main factors underlying dividend policy, we found a negative association between dividends and MBTV. Furthermore, the analysis showed a significant positive association between dividends and profitability. Logistic regression showed a positive association between 
lagged dividends and dividends, and an insignificant association with leverage, liquidity, firm size, tangible assets and life cycle. The research results show that trade-off theory, pecking order theory, agency theory, lifecycle theory and signalling theory, which seek to determine the main factors behind capital structure and dividend policy, are not applicable in the context of the KSA market. The analysis also illustrates that the interrelationship between dividend policy and capital structure is insignificant. The outcomes shown have significant implications for KSA firms' directors, shareholders, policy makers, and those involved in financing and dividend decisions. For example, these results suggest that policy makers concerned with financial stability should embolden modification, as it is likely to decrease risk, and shareholders may assume that KSA companies have lower liability and pay higher dividends. KSA policy makers have dedicated a great deal of effort to developing a robust economy. The KSA government should consider the sources of financing for corporate investment, and should provide a variety of choices that comply with Sharia by enhancing the operation of the Sukuk market. These options could work as an alternative to commercial bank loans as a source of financing. Moreover, regulators in KSA should simplify financing procedures, i.e. decrease the complications involved in funding programmes for firms, and should encourage banks, especially Islamic banks, to provide suitable funding for these firms. KSA supervisors should aim to develop a more effective equity market and should guarantee trustworthy and cost-effective sources of funding. With regard to dividend policy, KSA regulators should enhance the efficiency of credit and capital marketplaces. Companies that enjoy high levels of return have the ability to pay additional dividends (as compared to smaller companies with lower profitability), because larger firms have the ability to access market funding, have good links with banks, and find it easier to obtain loans. They should also give more consideration to problems involving agency costs, as these costs are the main factor underlying dividend policy. In addition, they should support shareholders' rights. Authorities in KSA should try to develop disclosure regulations for corporations in order to decrease the role played by dividends as a means for Regulator Company's administration

The key constraint of this study is that it is based on quantitative information taken from databases and annual reports; quantitative data may not include important elements that have an effect on funding and dividend decisions. For example, human factors such as attitudes, knowledge, and awareness may have an impact on board financing decisions. Further research may benefit from survey analysis in order to examine the influences of board features on financing and dividend decisions. As well, this research used annual statistics, rather than monthly or daily. Using annual data may decrease the accuracy of results relating to financing decisions because these decisions are a constant process and it is important to recognise and understand the factors affecting this process based on each time span. Using three-monthly statistics, for instance, could provide stronger evidence of the associations between variables. The third limitation of this study is that it used data related to a single country (KSA), which constrains the ability to generalise the results for other contexts. Finally, this research focused only on firm characteristics in order to explore the extent to which these affect capital structure and dividend policy.

Conducting surveys with managers and boards of directors may reveal the main factors affecting dividend decisions. Moreover, this could help to create an association between investment and financing and dividend decisions. This could be accomplished by asking executives about the influences affecting their decisions. Moreover, the core influences on capital structure and dividend choices will be explored. This could also be realised using a qualitative approach by conducting interviews with directors and shareholders. The outcomes of dividend policy may be improved where executives as well as shareholders share their thoughts concerning a company's dividend policy. Future 
research may also focus on more countries, such as Gulf Cooperation Council countries. Future models may also contain corporate governance mechanism variables such as board size, board independence, audit committee, institutional ownership, etc., which could clarify to what extent these variables have an influence on capital structure and dividend policy.

\section{References}

Acock, A. C. (2008). A gentle introduction to Stata. College Station, Texas: StataCorp LP.

Aggarwal, R., \& Kyaw, N. (2010). Capital structure, dividend policy, and multinationality: Theory versus empirical evidence. International Review of Financial Analysis, 19 (2), 140-150. https://doi.org/10.1016/j.irfa.2010.01.001

Aivazian, V., Booth, L., \& Cleary, S. (2003). Do emerging market firms follow different dividend policies from US firms. Journal of Financial Research, 26(3), 371-387. https://doi.org/10.1111/1475-6803.00064

Al-Ajmi, J., Abo Hussain, H.A., \& Al-Saleh, N. (2009). Decisions on capital structure in a Zakat environment with prohibition of riba: The case of Saudi Arabia. Journal of Risk Finance, 10(5), 460-476. https://doi.org/10.1108/15265940911001376

Aljamal, S. (2018). The practice of transformational management and its role in achieving institutional excellence from the point of view of workers in the Directorates of Education in Hebron. International Journal of Business Ethics and Governance, 1(1), 64-90. https://doi.org/10.51325/ijbeg.v1i1.12

Al-Malkawi, H. (2007). Determinants of corporate dividend policy in Jordan: An application of the Tobit Model. Journal of Economics and Administrative Sciences, 23(2), 44-70 .https://doi.org/10.1108/10264116200700007

Al-Najjar, B. (2009). Dividend behaviour and smoothing new evidence from Jordanian panel data. Studies in Economics and Finance, 26(3), 182- 197. https://doi.org/10.1108/10867370910974017

Al-Najjar, B. (2011). The inter-relationship between capital structure and dividend policy: Empirical evidence from Jordanian data. International Review of Applied Economics, 25(2), 209-224 .https://doi.org/10.1080/02692171.2010.483464

Al-Najjar, B., \& Hussainey, K. (2009). What drives firms' capital structure and dividend policy. Working paper, Middlesex University, London.

Al-Sakran, S. (2001). Leverage determinants in the absence of corporate tax system: The case of non- financial publicly traded corporations in Saudi Arabia. Managerial Finance, 27(10/11), 58 - 86. https://doi.org/10.1108/03074350110767583

Ambarish, R., John, K., \& Williams, J. (1987). Efficient signalling with dividends and investments. The Journal of Finance, 42(2), 321-343. https://doi.org/10.1111/j.1540-6261.1987.tb02570.x

Amidu, M., \& Abor, J. (2006). Determinants of dividend payout ratios in Ghana, Journal of Risk Finance, 7(2), 136-145. https://doi.org/10.1108/15265940610648580

Antoniou, A., Guney, Y., \& Paudyal, K. (2008). The determinants of capital structure: Capital market-oriented versus bank-oriented institutions. Journal of Financial and Quantitative Analysis, 43(1), 59-92 .https://doi.org/10.1017/S0022109000002751

Barclay, M., Holderness, C., \& Sheehan, D. (2009). Dividends and corporate shareholders. Review of Financial Studies, 22(6), 2423-2455. https://doi.org/10.1093/rfs/hhn060 
Barclay, M., Smith, C., \& Watts, R. (1995). The determinants of corporate leverage and dividend policies. Journal of Applied Corporate Finance, 7(4), 4-19. https://doi.org/10.1111/j.1745-6622.1995.tb00259.x

Beck, T., \& Levine, R. (2002). Stock markets, banks, and growth: Panel evidence )NBER Working Paper No. 9082). National Bureau of Economic Research.

Bennett, M., \& Donnelly, R. (1993). The determinants of capital structure: Some UK evidence. The British Accounting Review, 25(1), 43-59. https://doi.org/10.1006/bare.1993.1005

Bevan, A., \& Danbolt, J. (2002). Capital structure and its determinants in the United Kingdom-a decomposition analysis. Applied Financial Economics, 12(3), 159-170. https://doi.org/10.1080/09603100110090073

Bhaduri, S. (2002). Determinants of corporate borrowing: Some evidence from the Indian corporate structure. Journal of Economics and Finance, 26(2), 200-15. https://doi.org/10.1007/BF02755986

Bharath, S., Pasquariello, P., \& Wu, W. (2009). Does asymmetric information drive capital structure decisions? Review of Financial Studies, 22, 3211-3243. https://doi.org/10.1093/rfs/hhn076

Bradley, M., Jarrell, G., \& Kim, E. (1984). On the existence of an optimal capital structure: Theory and evidence. The Journal of Finance, 39(3), 44-67. https://doi.org/10.1111/j.1540-6261.1984.tb03680.x

Brav, A., Graham, J., Harvey, C., \& Michaely, R. (2005). Pay-out policy in the 21st Century. Journal of Financial Economics, 77(3), 483-527. https://doi.org/10.1016/j.jfineco.2004.07.004

Brockman, P., \& Unlu, E. (2009). Dividend policy, creditor rights, and the agency costs of debt. Journal of Financial Economics, 92(2), 276-299. https://doi.org/10.1016/j.jfineco.2008.03.007

Caglayan, E., \& Sak, N. (2010). The determinants of capital structure: Evidence from the Turkish banks. Journal of Money, Investment and Banking, 15, 57-65.

Cassar, G., \& Holmes, S. (2003). Capital structure and financing of SMEs: Australian evidence. Accounting \& Finance, 43(2), 123-47. https://doi.org/10.1111/1467629X.t01-1-00085

Chadha, S., \& Sharma, A. (2015). Determinants of capital structure: an empirical evaluation from India. Journal of Advances in Management Research, 12(1), 3-14. https://doi.org/10.1108/JAMR-08-2014-0051

Chang, R. \& Rhee, S. (1990). The impact of personal taxes on corporate dividend policy and capital structure decisions. Financial Management, 19(2), 21-31. https://doi.org/10.2307/3665631

Chang, X., \& Dasgupta, S. (2009). Target behavior and financing: How conclusive is the evidence. The Journal of Finance, 64(4), 1767-1796. https://doi.org/10.1111/j.1540-6261.2009.01479.x

Chaplinsky, S., \& Niehaus, G. (1993). Do inside ownership and leverage share common determinants. Quarterly Journal of Business and Economics, 32, 51-65.

Chay, J., \& Suh, J. (2009). Pay-out policy and cash-flow uncertainty. Journal of Financial Economics, 93(1), 88-107. https://doi.org/10.1016/j.jfineco.2008.12.001

Chen, C., \& Steiner, T. (1999). Managerial ownership and agency conflicts: A nonlinear simultaneous equation analysis of managerial ownership, risk taking, debt policy, and dividend policy. Financial Review, 34, 119-36. https://doi.org/10.1111/j.15406288.1999.tb00448.x 
Chen, J. (2004). Determinants of capital structure of Chinese-listed companies. Journal of Business Research, 57(12), 1341-1351. https://doi.org/10.1016/S01482963(03)00070-5

Cleary, S. (1999). The relationship between firm investment and financial status. The Journal of Finance, 54(2), 673-692. https://doi.org/10.1111/0022-1082.00121

Coulton, J., \& Ruddock, C. (2011). Corporate pay-out policy in Australia and a test of the life-cycle theory. Accounting and Finance, 51(2), 381-407. https://doi.org/10.1111/j.1467-629X.2010.00356.x

Crutchley, C., Jensen, M., Jahera, J., \& Raymond, J. (1999). Agency problems and the simultaneity of financial decision making: The role of institutional ownership. International Review of Financial Analysis, 8(2), 177-197. https://doi.org/10.1016/S1057-5219(99)00011-3

De Angelo, H., DeAngelo, L., \& Stulz, R. (2006). Dividend policy and the earned/contributed capital mix: a test of the life-cycle theory. Journal of Financial Economics, 81(2), 227-254. https://doi.org/10.1016/j.jfineco.2005.07.005

Degryse, H., De Goeij, P., \& Kappert, P. (2012). The impact of firm and industry characteristics on small firms' capital structure. Small Business Economics, 38(4), 431- 447. https://doi.org/10.1007/s11187-010-9281-8

Denis, D., \& Osobov, I. (2008). Why do firms pay dividends? International evidence on the determinants of dividend policy. Journal of Financial Economics, 89(1), 62-82 . https://doi.org/10.1016/j.jfineco.2007.06.006

Easterbrook, F. (1984). Two agency-cost explanations of dividends. American Economic Review, 74 (4), 650- 659.

Eckbo, B., \& Verna, S. (1994). Managerial share ownership, voting power, and cash dividend policy. Journal of Corporate Finance, 1(1), 33-62. https://doi.org/10.1016/0929-1199(94)90009-4

Eije, H., \& Megginson, W. (2008). Dividends and share repurchases in the European Union. Journal of Financial Economics, 89(2), 347- 374. https://doi.org/10.1016/j.jfineco.2007.11.002

Eldomiaty, T (2007). Determinants of corporate capital structure: evidence from an emerging economy. International Journal of Commerce and Management, 17(1/2), 25-43.

Fama, E., \& French, K. (2001). Disappearing dividends: Changing firm characteristics or lower propensity to pay. Journal of Financial Economics, 60, 3-43. https://doi.org/10.1016/S0304-405X(01)00038-1

Ferreira, A., \& Vilela, S. (2004). Why do firms hold cash? Evidence from EMU countries. European Financial Management, 10, 295-319. https://doi.org/10.1111/j.13547798.2004.00251.X

Ferris, S., Sen, N., \& Unlu, E. (2009). An international analysis of dividend payment behavior. Journal of Business Finance and Accounting, 36(3-4), 496-522. https://doi.org/10.1111/j.1468-5957.2009.02126.x

Flannery, M. \& Rangan, K. (2006). Partial adjustment toward target capital structures. Journal of Financial Economics, 79(3), 469-506. https://doi.org/10.1016/j.jfineco.2005.03.004

Frank, M., \& Goyal, V. (2003). Testing the pecking order theory of capital structure. Journal of Financial Economics, 67 (2), 217-248. https://doi.org/10.1016/S0304$\underline{405 X(02) 00252-0}$

Frank, M., \& Goyal, V.K. (2008). Trade off and pecking order theories of debt. In Eckbo, E. (ed.), The handbook of empirical corporate finance (pp.135-202). Elsevier. 
Friend, I., \& Lang, L. (1988). An empirical test of the impact of managerial self-interest on Corporate capital structure. The Journal of Finance, 43, 271-281. https://doi.org/10.1111/j.1540-6261.1988.tb03938.x

Fuller, K., \& Blau, B. (2010). Signalling, free cash flow and "no monotonic" dividends. Financial Review, 45(1), 21-56. https://doi.org/10.1111/j.1540-6288.2009.00236.x

Gaud, P., Jani, E., Hoesli, M., \& Bender, A. (2005). The capital structure of Swiss companies: An empirical analysis using dynamic panel data. European Financial Management, 11(1), 51-69. https://doi.org/10.1111/j.1354-7798.2005.00275.x

Gonenc, H. (2003). Capital structure decisions under micro institutional settings: The case of Turkey. Journal of Emerging Market Finance, 2(1), 57-82. https://doi.org/10.1177/097265270300200103

Grullon, G., \& Michaely, R. (2002). Dividends, share repurchases, and the substitution Hypothesis. The Journal of Finance, 62, 1649-1684. https://doi.org/10.1111/1540$\underline{6261.00474}$

Gugler, K., \&Yurtoglu, B. (2003). Corporate governance and dividend pay-out policy in Germany. European Economic Review, 47(4), 731-58. https://doi.org/10.1016/S0014-2921(02)00291-X

Harris, M., \& Raviv, A. (1990). Capital structure and the informational role of debt. The Journal of Finance, 45, 321-349. https://doi.org/10.1111/j.15406261.1990.tb03693.x

Ho, H. (2003). Dividend policies in Australia and Japan. International Advances in Economic Research, 9(2), 91-100. https://doi.org/10.1007/BF02295710

Hovakimian, A., Hovakimian, G., \& Tehranian, H. (2004). Determinants of target capital structure: The case of dual debt and equity issues. Journal of Financial Economics, 71(3), 517-540. https://doi.org/10.1016/S0304-405X(03)00181-8

Huang, J., Shen, Y., \& Sun, Q. (2010). Non-negotiable shares, controlling shareholders, and dividend payments in China. Journal of Corporate Finance, 17(1), 122-133. https://doi.org/10.1016/j.jcorpfin.2010.09.007

Huang, R. \& Ritter, J. (2009). Testing theories of capital structure and estimating the speed of adjustment. Journal of Financial and Quantitative Analysis, 44(2), 237271. https://doi.org/10.1017/S0022109009090152

Huang, S., \& Song, F. (2006). The determinants of capital structure: Evidence from China. China Economic Review, 17, 14-36. https://doi.org/10.1016/j.chieco.2005.02.007

Huizinga, H., Laeven, L., \& Nicodeme, G. (2008). Capital structure and international debt shifting. Journal of Financial Economics, 88(1), 80-108. https://doi.org/10.1016/j.jfineco.2007.05.006

Jensen, G., Solberg, A., Donald, P., \& Zorn, T. (1992). Simultaneous determination of insider ownership, debt, and dividend policies. Journal of Financial and Quantitative Analysis, 2, 247-63. https://doi.org/10.2307/2331370

Jensen, M., \& W. Meckling. (1976). Theory of the firm: Managerial behavior, agency costs and ownership structure. Journal of Financial Economics, 3, 305-360. https://doi.org/10.1016/0304-405X(76)90026-X

Jensen, M. (1986). Agency costs of free cash flow, corporate finance, and takeovers. American Economic Review, 76, 323-329.

John, K., \& Williams, J. (1985). Dividends, dilution, and taxes: A signaling equilibrium.

TheJournal of Finance, 40, 1053-70. https://doi.org/10.1111/j.15406261.1985.tb02363.x

Kania, L., \& Bacon, W. (2005). What factors motivate the corporate dividend decision? American Society of Business and Behavioral Sciences E-Journal, 1(1), 95-107. 
Khan, M., \& Bhatti, I. (2008). Development in Islamic banking: a financial risk-allocation approach. Journal of Risk Finance, 9(1), 40-51. https://doi.org/10.1108/15265940810842401

Koch, P., \& Shenoy, C. (1999). The information content of dividend and capital structure Policies. Financial Management, 28, 16-36. https://doi.org/10.2307/3666301

Kraus, A., \& Litzenberger, R. (1973). A state-preference model of optimal financial leverage. The Journal of Finance, 28(4), 911-922. https://doi.org/10.1111/j.15406261.1973.tb01415.x

Lang, L., \& Litzenberger, R. (1989). Dividend announcements: Cash flow signaling vs. free cash flow hypothesis. Journal of Financial Economics, 24, 181-192. https://doi.org/10.1016/0304-405X(89)90077-9

Leary, M., \& Roberts, M. (2005). Do firms rebalance their capital structures? The Journal of Finance, 60(6), 2575-2619. https://doi.org/10.1111/j.1540-6261.2005.00811.x

Lemmon, M., Roberts, M., \& Zender, J. (2008). Back to the beginning: Persistence and the cross-section of corporate capital structure. The Journal of Finance, 63(4), 15751608. https://doi.org/10.1111/j.1540-6261.2008.01369.x

Li, K., \& Zhao, X. (2008). Asymmetric information and dividend policy. Financial Management, 37(4), 673-694. https://doi.org/10.1111/j.1755-053X.2008.00030.x

Long, A., \& Malitz, A. (1986). The investment financing nexus: Some empirical evidence. Midland Corporate Finance Journal, 3(2), 122-137.

Miller, M., \& Rock. R. (1985). Dividend policy under asymmetric information. Journal of Finance, 40, 1031-51. https://doi.org/10.1111/j.1540-6261.1985.tb02362.x

Modigliani, F., \& Miller, M. (1958). The cost of capital, corporation finance and the theory of investment. Economic Review, 48, 261-297.

Myers, S., \& Majluf, N. (1984). Corporate financing and investment decisions when firms have information that investors do not have. Journal of Financial Economics, 13,187-221. https://doi.org/10.1016/0304-405X(84)90023-0

Myers, S., \& Rajan, R. (1998). The paradox of liquidity. Quarterly Journal of Economic, 113 (3), 733-771. https://doi.org/10.1162/003355398555739

Myers, S. (1977). Determinants of corporate borrowing. Journal of Financial Economic, 5, 147- 175. https://doi.org/10.1016/0304-405X(77)90015-0

Myers, S. (1984). The capital structure puzzle. The Journal of Finance, 39(3), 575-92. https://doi.org/10.2307/2327916

Naceur, S., Goaied, M., \& Belanes, A. (2006). On the determinants and dynamics of dividend policy. International Review of Finance, 6(1-2), 1-23. https://doi.org/10.1111/j.1468-2443.2007.00057.x

Ozkan, A. (2001). Determinants of capital structure and adjustment to long run target: Evidence from UK company panel data. Journal of Business Finance and Accounting, 28(1/2), 175-198. https://doi.org/10.1111/1468-5957.00370

Pandey, I., \& Bhat, R. (2007). Dividend behavior of Indian companies under monetary policy restrictions. An investigation of the Managerial Finance, 33(1),14-25. https://doi.org/10.1108/03074350710715782

Pandey, I., \& Chotigeat, T. (2004). Theories of capital structure: Evidence from an emerging market. Studies in Economics and Finance, 22(2), 1-19. https://doi.org/10.1108/eb028777

Patra, T., Poshakwale, S., \& Yong, K.O. (2012). Determinants of corporate dividend policy in Greece. Applied Financial Economics, 33(13), 1079- 1087. https://doi.org/10.1080/09603107.2011.639734 
Qureshi, M. (2010). Does pecking order theory explain leverage behavior in Pakistan. Applied Financial Economics, 19(17), 1365-1370. https://doi.org/10.1080/09603100902817592

Rajan, R., \& Zingales, L. (1995). What do we know about capital structure? Some evidence from international data. The Journal of Finance, 50(5), 1421-60. https://doi.org/10.1111/j.1540-6261.1995.tb05184.x

Rehman, A. (2012). Determinants of dividend payout ratio: Evidence from Karachi Stock Exchange. Journal of Contemporary Issues in Business Research, 1(1), 20-27.

Renneboog, L., \& Trojanowski, G. (2010). Patterns in pay-out policy and pay-out channel choice. Journal of Banking and Finance, 35(6), 1477-1490. https://doi.org/10.1016/j.jbankfin.2010.10.028

Ross, S. (1977). The determination of financial structure: The incentive signaling approach. Journal of Economics, 8(1), 23-41. https://doi.org/10.2307/3003485

Rozeff, M. (1982). Growth, beta and agency costs as determinants of dividend pay-out ratios. Journal of Financial Research, 5, 249-59. https://doi.org/10.1111/j.14756803.1982.tb00299.x

Saudi Arabian Monetary Agency (SAMA) (2015). 50th Annual Reports. https://www.sama.gov.sa/en-

US/EconomicReports/AnnualReport/5600_R_Annual_En_50_Apx.pdf.

Stulz, R. M. (1990). Managerial discretion and optimal financial policies. Journal of Financial Economics, 26(3) 1-27. https://doi.org/10.1016/0304-405X(90)90011-N

Titman, S., \& Wessels, R. (1988). The determinants of capital structure choice. Journal of Finance, 43(1), 1-19. https://doi.org/10.1111/j.1540-6261.1988.tb02585.x

Viviani, J (2008). Capital structure determinants: An empirical study of French companies in the wine industry. International Journal of Wine Business Research, 20(2), 171 194. https://doi.org/10.1108/17511060810883786

Voulgaris, F., Asteriou, D., \& Agiomirgianakis, G. (2004). Size and determinants of capital structure in the Greek manufacturing sector. International Review of Applied Economics,18(2), 247-62. https://doi.org/10.1080/0269217042000186714

Wiwattanakantang, Y. (1999). An empirical study on the determinants of the capital structure of Thai firms. Pacific-Basin Finance Journal, 7(3-4), 371-403. https://doi.org/10.1016/S0927-538X(99)00007-4

Yu, D., \& Aquino, R. (2009). Testing capital structure models on Philippine listed firms. $\begin{array}{lll}\text { Applied } \quad \text { Economics, } & \text { 41(15), }\end{array}$ https://doi.org/10.1080/00036840601131805

Zameer, H., Rasool, S., Iqbal, S., \& Arshad, U. (2013) Determinants of dividend Policy: A case of banking sector in Pakistan. Middle-East Journal of Scientific Research, 18 (3), 410-424. 